\title{
Diving in Sin and Resurfacing with the Discovery of the Self in Defoe's Robinson Crusoe
}

\author{
Khalid Sultan Thabet Abdu ${ }^{1}$ \\ ${ }^{1}$ Department of English, College of Science and Humanities, Prince Sattam bin Abdulaziz University, Saudi \\ Arabia \\ Correspondence: Khalid Sultan Thabet Abdu, Department of English Language, College of Science and \\ Humanities at Al- Aflaj, Prince Sattam bin Abdulaziz University, P.O. Box 710, Al-Aflaj 11912, Saudi Arabia. \\ E-mail:k.abdu@psau.edu.sa
}

Received: February 12, 2020 Accepted: March 14, 2020 Online Published: March 21, 2020

doi:10.5539/ijel.v10n3p203 URL: https://doi.org/10.5539/ijel.v10n3p203

\begin{abstract}
This paper attempts to study the novel of Robinson Crusoe from the perspective of Eurocentric discourse of travel. The paper sheds light on Western hegemony of travel from the metropolis to the peripheries for the sake of discovering and colonizing the "Other" parts of the world in one hand; on the other hand, these journeys enable the protagonist to grow physically, psychologically, spiritually and mentally. The paper also traces the physical journey that coincides with the inner journey which results in the self-discovery of the protagonist of himself as sequences of gradual growth from childhood to maturity; this trait makes the novel as bildungsroman. The protagonist commits a sin of disobedience at the beginning of his life and he has to endure all difficulties of life because of that deadly sin and with the passage of time he discovers his mistakes and repents from his wickedness and comes back to God who redeems him from his original sin. Therefore, he discovers himself after reaching the stage of wisdom, maturity and repentance. He has also been redeemed and awarded the fruitfulness of his endurance by reaching his father's house again and reunited with his family.
\end{abstract}

Keywords: hegemony, colonial travel writing, sin, self-discovery, bildungsroman, redemption

\section{Introduction}

Stories of travel have been popular since immemorial times. Homer's Odyssey is the earliest tales of these travel books which is followed by Lucian's True History. Plato in his great book Republic tackles the ideal society in which he calls it Utopia. This Utopian society is an imaginary inspiration for travellers to find it through their journeys of exploration. As a matter of fact, literature attempts to explore man's sprite of curiosity which leads him to travel throughout the world to find this ideal society. In this regard, Charles Larson points out that, "Literature is a bridge connecting a life lived with a life not lived, so, too, all literature that is effective is a voyage into a previously untraveled world." (65). Travel literature starts with religious journeys to sacred spot that includes pilgrimages. Such journey is clearly seen in Chaucer's The Canterbury Tales in which the poet shows the voyages of pilgrims to Canterbury. Besides, there are also many pilgrims who perform their religious journeys to the east, Rubies notes, "the seventeenth century-writers like George Sandys in his A Relation of a Journey [. . . (1615) — in effect transformed a pilgrimage to Holy Sites into a 'Grand Tour' of the East, often combining ethnography with antiquarianism" (248). Tabish Khair in his book Other Routes: 1500 Years of African and Asian Travel Writing defines the genre of travel writing as "the writer's relationship to a geographical area, its natural attributes and its society and culture; and, just as significantly, the writer's relationship to his or her own society and culture" (4). Joan Pau Rubies confirms, "The description of peoples, their nature, customs, religion, forms of government, and language, is so embedded in travel writing" (242). Mary Louise Pratt in her study, Imperial Eyes, compares Europeans with the other nations of the world, as Westerners consider themselves superiors than the other nations of the world and this feature has led to "constructing modern Eurocentrism" (15). Therefore, Europeans impose their ideology of power to control the others by using the language to control minds; and in this regard, Abdu and Khafaga point out that, "Language is seen as a means of controlling minds and shaping attitudes" (421).

Robinson Crusoe is a novel of journey and discovery of the self. The novel starts with the elopement of the protagonist from his father's house seeking for utopian society. He performs five main journeys in three 
continents that include Europe, Africa and South America and such great experience of travelling reshapes his identity. The aim of this study is to find out how journey plays a vital role to enlarge the protagonist's comprehension of the world around him and of his understanding of himself as a whole.

\subsection{Objective of the Research}

This paper aims to analyze Daniel Defoe's Robinson Crusoe from the perspective of Eurocentric discourse of travel and at the same time it examines how physical journey coincides with the inner journey to shape the identity of the protagonist in the process of his self-discovery.

\subsection{Research Questions}

How does journey play a vital role to form identity?

How does journey enrich our comprehension of the world?

What is the importance of journey in the process of self-discovery?

\section{Methodology}

This research scrutinizes the content of Daniel Defoe's Robinson Crusoe from the perspective of Eurocentric discourse of travel, as the main character travels from the metropolis to the peripheries of the world. The study shows how journey shapes and reshapes his identity through the process of his discovery of the outside world as well as his inner side world. Therefore, methodologically, the paper investigates this notion in the selected text via the joint venture of the theory of colonial discourse, post-colonialism as well as critical discourse analysis. In critical discourse analysis, the paper focuses on Bill Ashcroft's Postcolonial Studies Reader that deals with using dichotomies of West-the other parts of the world, culture-nature, and coloniser-colonised. It also deals with Mary Louise Pratt's Imperial Eyes: Travel Writing and Transculturation, as this book tackles the conception of Eurocentrism and at the same time the book justifies European journeys from metropolis to peripheries. Besides, the study also emphases on Edward Said's Orientalism and its division of Orient-Occident relationship with especial focus on Western journey motif, as western journey must be directed from the Centre to the other parts of the world, Said says, "it was the West that moved upon the East, not vice versa" (73). The paper also sheds light on other critics worldwide and shows their opinions about this colonial text, a Chinese critic Haifeng Huil, as a case in point, approaches this novel from political perspective by criticizing Western cultural hegemony.

\section{Discussion}

Generally, Europe witnesses so many progresses during Renaissance Period which is called the age of exploration by sea. Navigators use the compass to explore new continents and the results of their exploration is Christopher Columbus's discoveries of the new lands of North and South America as well as some other parts of the old continents. According to the paradigm of the Eurocentric discourse of travel, voyagers are destined to travel in a one-way direction from the metropolis to the peripheries. Edward Said in his Orientalism remarks, "it was the West that moved upon the East, not vice versa" (73). In this regard, the arrival of Portuguese to the East brought with itself European superiority and colonialism in the sense that "Europeans could claim to be able to understand and interpret not only the terrain they entered but the inhabitants as well" (Bridges 53). In the meantime, "The systematizing of nature," suggested by Pratt, is a "European project of a new kind, a new form of what one might call planetary consciousness among Europeans" (29). Therefore, the Portuguese navigation enhanced the essential role of Europeans in the East; in this regard Pratt writes, "Circumnavigation and mapmaking, then, had already given rise to what one might call a European global or planetary subject" (30). Europeans approached the periphery to implement their own enterprise of discourse; as Pratt points out, their conception is that of "an urban discourse about non-European worlds, and a lettered bourgeois discourse about non-lettered, peasant worlds" (34-35). With the coming of the Europeans to the "Other" parts of the world, dichotomies between Europe and its others came to existence; hence, "A line is drawn between two continents. Europe is powerful and articulate; Asia is defeated and distant" (Said 57).

Hence, the movement of people is just from the Centre to periphery, as the Centre is holding power and plays a vital role to enlighten the peripheries. Besides, the history of Western writing could be described as the history of European writing about the other parts of the world, especially the countries they colonised. Colonisation, in turn, led to confrontation between cultures and an awareness of the dichotomies between culture and nature, coloniser and colonised. European travel accounts to the other parts of the world can be classified into several categories: exploration, curiosity, missionary, diplomacy, and trade activity; their travels include most of the continents which stretch from the Western to the Eastern coastal cities of the world (Abdu, 74). The eighteenth century witnesses the expansion of European travellers to the rest of the globe; thus, a paradigm of travel writing emerges in the form of picturesque or exotic narration. Many established writers have either produced travel 
books or have used travel as a major structural motif in their works. The focus is more on science and precision and the focal feature of this narrative is the mixing up of facts and fiction as it is obviously exemplified in Robinson Crusoe (1719), in which Defoe transforms his journey into a travel book. Therefore, exploration of the new world opens the gate widely for writers to explore the new lands and this is shown clearly in Daniel Defoe's Robinson Crusoe. This paper attempts to explore how the protagonist discovers himself via his sin which is committed at the beginning of the novel.

The idea of the novel, Robinson Crusoe, comes to the mind of Daniel Defoe while reading the story of Juan Fernandez on the newspaper of The Englishman. The novel was based upon the actual experiences of a real sailor called Alexander Selkirk (1676-1721) who had spent four years alone, all alone in the island of Juan Fernandez, off the west coast of South America, after a big dispute with the captain of the ship. Therefore, the captain left him alone as a kind of punishment and then spent four years in that desolate island. He was rescued in 1711 by captain Woodes Rogers who gave an account of Selkirk's experiences in his book A Cruising Voyage Round the World (1718). Selkirk came to London in 1711 and told his real story to Richard Steele who helped to publish it in The Englishman in 1713 (Swift, XIV). While recognizing this we must admit that the hero of this novel, Robinson Crusoe, is an imaginary character and that, there is resemblance between Selkirk's life on the actual island of Juan Fernandez and Crusoe's life on an imaginary island. Defoe's story of Crusoe's experiences and activities is largely fictitious.

Robinson Crusoe seems to be a novel of travel and adventure from the surface structure of the novel. The protagonist is the only one in the family who is still alive while the others two brothers of him perished, as one is killed and the second one is missing, so the father does not want the third son to leave him. Very early in life, his head began to be filled with "rambling thoughts". The novel starts with the argument between the son and his father, as the father is trying his best to convince his son to study law and not to go to the sea, but the son has strong feeling to go to the sea. What is prohibited for the son becomes desirable and he wants to discover what is behind the horizon as he says, "my head began to be filled very early with rambling thoughts" (1). Besides, he pays no attention to his father's advice and wants to fulfill his own dreams by saying, "I would be satisfied with nothing but going to sea" (1). According to Crusoe, he considers that travelling abroad is one way of achieving his goals and desires; moreover, he has a great believe in Utopian Society. Morteza Yousof and his coeditors in their paper "Reading Robinson Crusoe from the lens of Islamic Utopianism" note:

A human being longs to make the society he is living in a utopian one. In other words, a person's effort is concentrated towards developing a better self at the individual level and then when it comes to the broader stage of society, everyone yearns for living in a utopian society. We contend that the idea of expecting a savior derives from the belief in utopianism which is an important facet in Robinson Crusoe. That is, there must be a savior who will come and rescue the world from tyrannies and injustices and to move the world towards its perfection. (188)

The son does not dare to speak to his father that he takes his decision to leave the house, but he speaks to his mother of his intention to travel and the mother reveals this fact to the father and Crusoe says, "if I [Crusoe] did take this foolish step, God would not bless me, and I would have leisure hereafter to reflect upon having neglected his counsel when there might be none to assist in my recovery" (1). Even though his father attempts to convince him to give up his thoughts of travelling and to stay with him, but all his attempts were in vain as the son reaches the age of eighteen and takes his final decision, "I resolved to run quite away from him" (4). Therefore, the novel starts with a sin of disobedience of Robinson Crusoe to his father and his departure to the sea. Robinson Crusoe's father makes a prophecy for his son by saying, "That boy might be happy if he would stay at home, but if he goes abroad, he would be the most miserable wretch that was even born. I can give no consent to it" (4).

The first journey starts from the city of Hull heading for London by a ship. It is the first experience for the protagonist, as he consults neither his father nor his mother. The date of the first journey, "on the first of September, 1651, I went on board ship bound for London." (5). Unfortunately, the ship faces many violent storms and sinks and the sailors throw their boats to the sea and row till they reach the land. This first journey with its horrible experience makes the hero to rethink again about his intention of going abroad especially when he reaches London. However, he changes his thoughts of coming back to his father's house because of feeling too shame of facing his family with his own guilt.

The second journey is from Europe to Africa exactly from London to Guinea and this expedition comes under the category of maritime trade from the Centre to periphery. Robinson Crusoe's mind is occupied with trade activities and suddenly he finds a captain of an English ship that goes from London to Guinea. Fortunately, the 
captain offers Crusoe with all possible facilities, as he takes him free of charge and not only that, but he also offers him with the following suggestion, "if I carry anything with me, I should have all advantages of it that the trade would admit; and perhaps I might meet with some encouragement" (13). Crusoe brings certain goods from London according to the advice of the sea-captain; he sells them in Guinea and at the same times brings goods from Africa and selling them in London. Crusoe's chief motive in travelling to Guinea is profit; and he does not mind going to the remotest part of the world in quest of profit. He is a commercial traveller par excellence, with the whole world as his territory. Silvia Antosa clarifies that Crusoe is, "the archetype of the eighteenth-century English merchant who embarks on new journeys for business purposes" (63). Unfortunately, the ship is attacked by Turkish pirates on its way to Guinea and all sailors have been taken hostages. Besides Robinson Crusoe's life is entirely changes from a respected European trader to a miserable slave, as he says, "At this surprising change of my circumstances from a merchant to a miserable slave, I was perfectly overwhelmed; and now I looked back upon my father's prophetic discourse to me, that I should be miserable and have none to relieve me" (15). He comes to realise that the prophecy of his father comes true and he lives in this miserable slavery for two years. Robinson Crusoe gives his master an indication that he is loyal to him and his master trusts him to go deep in the sea for fishing, but Robinson Crusoe gets the chance to escape by a Portuguese ship to Brazil.

The fourth journey is from Africa to Brazil. After the discovery of the new continents by Christopher Columbus, Brazil becomes one of the most interesting countries for new settlers coming from Europe. Robinson Crusoe represents Europeans who go to the new land for exploiting the new lands. The moment he treads upon the land of Brazil, he starts thinking of buying plantations as much as he can; in this regard, Robinson Crusoe says, "I purchased as much land that was uncured as my money would reach and formed a plan for my plantation and settlement" (29). His primary motive is to gain economically by investing his money in agriculture. Besides, his secondly motive is to have slaves; Rebecca Wolpe points out, "the hero, Robinson, spends a number of years as a plantation owner in Brazil, where he owns slaves - an acceptable and standard part of colonial existence" (58). It is not only that but Crusoe's career is specifically based on dealing with exploitation of those voyagers in order to assist the development of capitalism by providing the gold, the slaves and the tropical products on which the expansion of trade depended. Such voyagers had continued this process through the seventeenth and eighteenth centuries by developing colonies and world markets on which the further progress of capitalism depended. Robinson Crusoe realizes that he has a lot of plantations and he is in need of other people to cultivate the crops, so he says, "I mean in the advancement of my plantation; for the first thing I did, I bought me a Negro slave and a European servant also" (32). He realises that he is in need of human resources to increase his agricultural production. Therefore, he arranges a meeting with his landlords' neighbors' who represent agricultural feudalism and the meeting results in sending a ship to Guinea to buy Negros: "They listened always very attentively to my discourses on these heads, but especially to that part which related to buying Negroes" (33).

The fifth journey is from Brazil to Guinea for buying Negros. After spending almost four years in Brazil and having become fairly prosperous. Crusoe joins a few merchants who arrange a slave-buying expedition to Africa. European landlords in Brazil expand their plantations and they want more labours to work there in order to increase their agricultural productions, as Robinson Crusoe says, "they told me that they had a mind to fit out a ship to go to Guinea" (33). Therefore, they send a big ship to bring Negros from Guinea and the total sailors who board the ship are seventeen people. After twelve days' journey in the sea heading to Africa, they face an enormous storm that makes the ship hitting some rocks and then sinks; the only survivor is Robinson Crusoe while the whole other sailors have been perished. It is not easy for a Robinson Crusoe to find himself in a very critical situation and to observe that he is the only person left alone in a desolate island, he says, "I cannot describe, reflecting upon all my comrades that were drowned and that there should not be one soul saved but myself" (40). He starts to challenge the harsh condition of life by focusing on four essential elements which include "health and fresh water", "shelter from the heat of the sun", security from dangerous creatures and "a view of the sea". In this regard, Juan De Dios Torralbo Caballero remarks that "The construction and the content of Robinson Crusoe is a challenge to certain literary traditions preceding it, such as travel literature or even spiritual allegorical journeys" (20).

Robinson Crusoe is a practical man and he starts to adjust with the harsh reality of his new life in that desolate island. The novel deals with the relationship between a man and nature and how can a man defeat nature and adjust with the unusual soundings. The first thing that the protagonist thinks about in the island is to establish a proper habitation for himself up to the mountain with a view of the sea and away from ravenous creature. Crusoe learns to weave baskets from the twigs which he can easily cut from trees. Then, he starts to entertain himself by taming animals around him and lives with them, as he considers these living creatures a source of amusement that enable him to overcome the boredom of isolation. He has brought a dog and a couple of two cats from the 
stranded ship, and he has also caught a parrot and taught it to speak. Besides, he keeps goats within the fence of his house and gets many benefits from them like milk, wool, meat and skin. In addition to that, he grows corns and when he harvests the crops he grinds them and makes bread. Crusoe is really able to face all difficulties of life and to provide himself with all kind of amenities and comforts by his ingenuity, skill and labour. In this regard, Srinivas Aravamudan in his paper "East-West Fiction as World Literature: The Hayy Problem Reconfigured" points out that,

The solitary man in a hostile environment, who survives, endures, and eventually dominates his surroundings. This utopian element of philosophical romance, uniting "man" and "world" in heroic encounter and mutual redefinition, derives from many cultural contexts. However, the original fiction (within which Crusoe stays on the island for around twenty-eight years) has dominated the global cultural imagination to the exclusion of the two sequels that Defoe wrote within the year. (213)

Many critics criticise this novel because it glorifies the relationship between coloniser-colonised. It deals with binary opposition and exemplifies dichotomies of culture-nature, colonizer-colonized, White-black, Europe-the rest of the world, civilised-savages, educated-uneducated, modern-ancient and metropolis-peripheries. A Chinese critic, Haifeng Huil, approaches this novel from political perspective by saying:

Chinese scholars' enthusiasm in adopting political readings of Defoe may also be related to the national, cultural and ideological underpinnings of Chinese identity in the academic field to differentiate their studies in the international community and at the same time to resist western cultural hegemony. The result is a somewhat contradictory situation that mainly adopts western critical approaches, follows western academic trends, yet at the same time consciously criticizes its dominance and Eurocentrism. (720)

When the European, Robinson Crusoe, comes to this desolate island, he appoints himself as a king of the island. He gives a new name to the island, as he names it "the island of Despair" (61). He considers the whole island as his own territory and everything belongs to him, as he is also a law-giver and a master of the whole land. During his expeditions for discovery of the hidden parts of the island, he encounters with many cannibals killing two of them and enslaving the third one and having him as a slave. In other words, Crusoe saves one of the Cannibals from killing and in return the slave wants to show his loyalty to Crusoe by kneeling down, he "kissed the ground, and laid his head upon the ground, and, taking me [Crusoe] by the foot, set my foot upon his head; this, it seems, was in token of swearing to be my slave forever; I took him up, and made much of him, and encouraged him all I could" (182). He gives a new name to his slave and having depriving him from his real name and granting him an English name by calling him "Friday". In fact, Friday and his companions represent the real citizens of the island, whereas Crusoe embodies the European intruder to the island. However, the invader becomes the real ruler of the island and the real inhabitants are deprived from everything including their original names. In this regard, Bill Ashcroft and his coeditors in an essay "Ethnicity and Indigeneity", indicate that, "As a geographical myth the centre/margin binarism leads by logical extension to such absurdities as the idea that all people in colonies are marginalised while nobody at the imperial centre can be marginalised; or, more crudely, that whites are the colonisers and blacks the colonised." (213). Moreover, Robinson Crusoe being a coloniser who starts to dictate his own orders and instructions to Friday, he says to him, "I likewise taught him to say Master, and then let him know that was to be my name; I likewise taught him to say Yes and No and to know the meaning of them" (185). Therefore, he teaches him three important words and these are Master, yes and no. These words show the nature of relationship between the master and slave as the slave should always say yes to his master without any arguments. The relationship between Crusoe and Friday resembles the same relationship between Prospero and Caliban; it is this kind of friendship of enslavement that links a slave to his master. Helen Tiffin in his study "Post-colonial Literatures and Counter-discourse" argues that:

Like William Shakespeare's The Tempest, Robinson Crusoe was part of the process of 'fixing' relations between Europe and its 'others', of establishing patterns of reading alterity at the same time as it inscribed the 'fixity' of that alterity, naturalising difference within its own cognitive codes. But the function of such a canonical text at the colonial periphery also becomes an important part of material imperial practice, in that, through educational and critical institutions, it continually displays and repeats for the colonised subject, the original capture of his/her alterity and the processes of its annihilation, marginalisation, or naturalisation as if this were axiomatic, culturally ungrounded, 'universal', natural. (98)

With the passage of time, Robinson Crusoe controls everything in the island and he considers all people as his own subjects, the island as his kingdom and everything in the island belongs to him. He resembles the character of Kurtz in Heart of Darkness. Like the European Kurtz in Heart of Darkness when he considers everything belongs to him in the inner station in Africa, saying "My Land", "My River", "My Intendant" (Conrad, 72); 
Crusoe also regards everything in the island belongs to him. In other words, Robinson Crusoe colonises the people and the land and he appoints himself as the king of the island. Besides, he is proud of himself and of his property and of his subjects by saying,

My island was now peopled, and I thought myself very rich in subjects; and it was a merry reflection, which I frequently made, how like a king I looked. First of all, the whole country was my own mere property, so that I had an undoubted right of dominion. Second, my people were perfectly subjected. I was absolute lord and lawgiver; they all owed their lives to me, and were ready to lay down their lives, if there had been occasion of it, for me. (217)

The novel also can be read as a version of bildungsroman because it deals with the educational process of the protagonist from childhood to maturity. In other words, the novel starts with a sin of disobedience of the hero to the instruction of his father; his father told him not to go to the sea, but he insisted on going to the sea. This is considered as a fatal problem (Aristotle in his book The Poetics call it hamartia) and the suffering of the central character continues throughout the entire novel due to his error of judgment. In his first experience in life, the ship is damaged and he is rescued and this incident enables him to understand his sin and to re-think of coming back to his father's house again especially when he reaches London. However, it is the feeling of too much shame to face his parents as well as society with his own guilt that prevents him to do so. Crusoe says, "it immediately occurred to me how I should be laughed at among the neighbors and should be ashamed to see not my father and mother only but even everybody else" (12). Therefore, it is the feeling of humiliation that hinders him to return to the right path and then he goes on in his journey of life seeking for utopian society. In his second experience when he reaches Africa and encounters with Turkish pirates as a result of that he is enslaved and his entire situation changes from a merchant to a miserable slave. Immediately, he recognises his sin for being in this terrible condition due to the consequences of his disobedience, he notes: "and now I looked back upon my father's prophetic discourse to me, that I should be miserable and have none to relieve me" (15). However, in his third experience with dreadful situations especially when he settles in the island and faces the most terrorizing events of getting sick alone, encountering with cannibals and facing his own European people, as all events are responsible for his true return to God. When he becomes sick in the island, he finds no one to help him to overcome his health problem; therefore, he only finds the gate of God is widely open for him and this encourages him more to worship God. His spiritual growth is clearly perceived in one day that was on June 27 when he was very ill, he says "I was ready to perish for thirst but so weak I had not strength to stand up or to get myself any water to drink. Prayed to God again. He is always calling God and appealing to Him, "I carried out, "Lord, be my help, for I am in great distress" (81). He gets comfort from these words of God and then he overcomes his stress and tension. In another incident, when he discovers the footsteps of cannibals in the sea-shore and he notices that the footsteps are much larger than his ones indicating that these people living around him are very big; then, immediately he comes back home looking upon the Bible and starts to read the Bible and the first words that occur to him in the Bible, "Call on Me in the day of trouble, and I will deliver, and thou shalt glorify Me" (83). Later on, he realizes that he is not alone in this desolate island, but he is also sharing this island with cannibals and they are living with him somewhere in this land. After he discovers that the island is inhabited by cannibals, he is terrified to the highest degree. He shows his furious situation by, "looking behind at every two or three steps, mistaking every bush and tree, and fancying every stump at a distance to be a man" (138-9). Therefore, he becomes so frightened and is living in tension, as he does not know what to do and how to face them in case they come in great number to hit him by using arrows from all directions. All of these horrible thoughts stop him from sleeping for days and nights hasten the process of bringing him back to God. Hence, he divides his time in the island to perform three duties: the first duty is to worship God and read the Bible, the second duty is to hunt animals and the third duty is to cook what he has hunted. In this way, he notices that it is only through the way of God, he will be protected, redeemed and saved and there is no alternative way; that is the main reason of making the first priority towards God. Thus, Crusoe repents of his disobedience, and then eventually returns to his God. After repentance of his sin, Crusoe recognises the fact that he has been treated by the creator most mercifully, and that God has sweetened his bitter life on the island with his generosity. Ultimately, God has also sweetened his life by sending him a ship that carries him to his country after spending thirty-five years away as a penance of his sin. Crusoe says: "And thus I left the island, the 19th of December, [...] in the year 1686, after I had been upon it eight-and-twenty years, two months, and nineteen days" (250). He is reunited with his family after being absent for a very long time; he says, "I arrived in England, the 11th of June, in the year 1687, having been thirty-and-five years absent." (250). Therefore, Robinson Crusoe is certainly not only an adventure story, but it is much more than the boy story. It is rich in symbolic meanings and religious allegory. It depicts the original sin of which a man finds himself guilty, and the consequences of which he has to endure. The message of Defoe is that the hero should repent of his sin. The novel depicts the spiritual 
development of Crusoe, his recognition of his original sin, his repentance, his self-reform, in short, his religious conversion.

\section{Conclusion}

Robinson Crusoe is considered as a novel of various excursions covering three continents that leads to discovery of the self. In other words, it explores physical journey that coincides with inner journey which results in the discovery of the protagonist of himself. The novel starts with the incident of disobedience of the protagonist, as he decides to leave his father's house going abroad seeking for utopian society due to his rambling thoughts that occupied his mind. He goes on in his journey leaving his father's advice aside. The physical journeys are represented by five main journeys starting from Hull to London, from London to Guinea, from Guinea to Brazil, from Brazil to the fictional land "Despair Island" and finally from Despair island to London. Journeys in general play essential role to enlarge human comprehension of the world around him and of his understanding of himself as a whole. People who travel a lot know more about different cultures worldwide, religions, nations and civilizations, so they have the experience of accepting diversity by living with multicultural, multilingual, multi-religious, and multinational communities. This new environment enables the hero to enrich his experience greatly by moulding his consciousness according to the demands of the intercultural interactions. It is this new milieu of cosmopolitan society which hybridises different cultures, subjecting their sign-systems to a drastic and irretrievable mobilisation of codes. This is exactly what has happened to Robinson Crusoe, he travels a lot and mixes up with multicultural communities in three continents including Europe, Africa and America and experiencing the life of a trader, a slave, a landlord and a ruler; as a result of this intensive experience in life, he comes to the state of discovering the world as well as discovering his inner self. Therefore, this paper comes to conclude that a sin leads to journeys and journeys lead to the discovery of the world in general and of the self in particular.

\section{Acknowledgements}

We take this opportunity to thank Prince Sattam Bin Abdulaziz University in Saudi Arabia alongside its Deanship of Scientific Research, for all technical support it has unstintingly provided towards the fulfillment of the current research project.

\section{References}

Abdu, K. (2019). Expeditions for Discovering and Monopolising the East in the Pre-colonial, Colonial and Post-colonial Periods. International Journal of Applied Linguistics \& English Literature, 8(1), 71-77.

Abdu, K., \& Ayman, F. K. (2019). A Critical Discourse Analysis of Mind Control Strategies in George Orwell's Nineteen Eighty-Four. International Journal of English Linguistics, 9(6), 421-430. https://doi.org/10.5539/ijel.v9n6p421

Antosa, S. (2008). Formal and Thematic Influence of Travel Writing on the Novel: from the Pilgrims' Accounts to Defoe. Fogli di Anglistica: Rivista di Studi Inglesi (anno II n. 3-4, pp. 55-66). Print.

Aravamudan, S. (2014). East-West Fiction as World Literature: The Hayy Problem Reconfigured. Eighteenth-Century Studies, 47(2), 195-231. https://doi.org/10.1353/ecs.2014.0001

Ashcroft, B. et al. (Eds.) (1995). Postcolonial Studies Reader. London: Routledge.

Bridges, R. (2002). Exploration and Travel outside Europe. In H. Peter \& Y. Tim (Eds.), The Cambridge Companion to Travel Writing (pp. 53-67). Cambridge: Cambridge UP. https://doi.org/10.1017/CCOL052178140X.004

Caballero, J. (2019). I Found Pen, Ink and Paper [...] I Kept Things very Exact. Genreness in Robinson Crusoe. British and American Studies, 25, 15-24.

Conrad, J. (2011). Heart of Darkness. Beirut: York Press.

Defoe, D. (2015). Robinson Crusoe. Beirut: York Press.

Huil, H. F. (2018). Literary classics, consumer culture, and Chinese children's educational book market: material parameters and thematic adaptations in new curricular editions of Robinson Cruso. Neohelicon, 45(2), 711727. https://doi.org/10.1007/s11059-018-0437-x

Khair, T. et al. (eds.) (2005). Other Routes: 1500 Years of African and Asian Travel Writing. Bloomington: Indiana UP.

Larson, C. (1995). The Idea of Universality in Literature. In A. Bill et al. (Eds.), Postcolonial Studies Reader (pp. 62-65). London: Routledge. 
Pratt, M. L. (1992). Imperial Eyes: Travel Writing and Transculturation. London: Routledge.

Rubies, J.-P. (2002). Travel Writing and Ethnography. In H. Peter \& Y. Tim (Eds.), The Cambridge Companion to Travel Writing (pp. 242-260). Cambridge: Cambridge UP. https://doi.org/10.1017/CCOL052178140X.015

Said, E. W. (1995). Orientalism. New Delhi: Penguin.

Swift, J. (2013). Gulliver's Travels (pp. XIV-XXVII). Beirut: Routledge.

Tiffin, H. (1995). Post-colonial Literatures and Counter-discourse. In A. Bill et al. (Eds.), Postcolonial Studies Reader (pp. 95-98). London: Routledge.

Wolpe, R. (2012). From Slavery to Freedom: Abolitionist Expressions in Maskilic Sea Adventures. AJS Review, 36(1), 43-70 https://doi.org/10.1017/S0364009412000025

Yousofi, M. (Eds.) (2014). Reading Robinson Crusoe from the lens of Islamic Utopianism. International Journal of Applied Linguistics \& English Literature, 3(2), 187-193. https://doi.org/10.7575/aiac.ijalel.v.3n.2p.187

\section{Copyrights}

Copyright for this article is retained by the author, with first publication rights granted to the journal.

This is an open-access article distributed under the terms and conditions of the Creative Commons Attribution license (http://creativecommons.org/licenses/by/4.0/). 